\title{
The Adaptation Strategy of Fishermen Households in the Overfishing Areas of East Java
}

\author{
Anas Tain \\ University of Muhammadiyah Malang \\ tain_umm@yahoo.co.id ; anas@umm.ac.id
}

\begin{abstract}
Abstarct. The aims of this study are to analyze the adaptation strategies undertaken by fishermen households coping with socio-economic changes and fishing grounds for those who have been over fishing. This research was conducted in survey in relation to finding general descriptions of various adaptation done by fishermen households. Sampling technique used in this research is Multi Stage Cluster Sampling. The collected data is further analyzed descriptively. The results showed that the patterns of adaptation among the fishermen community to adjust the ecosystem of the marine physical environment and surrounding social-economic environment. The process of adaptation by fishermen households is not only done in fishing activities, but also in others' work on the ground for household members. The various forms of adaptation carried out by fisherfolk households are basically attempted to maintain survival, by earning income from other sources.

Revenues earned are expected to meet the needs of the household properly. Often, the income earned suffices to meet subsistence needs, which require the fishermen to reduce their consumption expenditures.
\end{abstract}

Keywords: adaptation, consumption, ecosystem, income, survival.

\section{INTRODUCTION}

The fishermen households living in over fishing areas of East Java face many problems such as poverty, unhealthy competitiveness at fishing zones, various socio-economic problems, the marine physical environment ecosystem, in which the problems have challenged fishermen households to adjust their living [1]. In line with this adjustment, the fishermen enable themselves to adapt

their living to their best environment, or so-called adaptation.

The occurrence of scarcity of fish resources poses a threat to the economic sustainability of fishermen households. Maintaining the survival of all household members of fishermen are expected to adapt their living to local social systems. In accordance with Talcott Parsons Functional Structural theory, there are four important functions required by all social systems: adaptation, goal attainment, integration, and latency [2].
The functional adaptation of social systems shows that the system must cope with critical external situations. The system must adapt people's necessity to their environment and adjust it to their needs. The functional adaptation is carried out by the economic subsystem [3], which is adapted by fishing households to maximize their welfare [4].

The several existing studies have examined fishermen's adaptations on climate change, ecology, and partially on socioeconomics [5] [6] [7]. The aims of this study are to analyze the adaptation strategies undertaken by fishermen households coping with socio-economic changes and fishing grounds for those who have been over fishing.

\section{METHOD}

This research was conducted in survey in relation to finding general descriptions of various adaptation strategies by fisherman households in the over fishing areas in East Java. The research was conducted in Jatirejo Village, Lekok Sub-District, Pasuruan Regency and Paciran Village, Paciran Sub-District, Lamongan Regency, wherein the status of fishery resources of the two villages was categorized in over fishing.

Sampling technique used in this research is Multi Stage Cluster Sampling. In the first phase, the status of fishery resource was over fishing, and selected two districts / cities (Pasuruan and Lamongan) in East Java. In the second stage, from two selected cities, each city is selected according to two sub-districts (Lekok and Paciran). In the third stage is village / kelurahan selection in which each selected sub-district has the first village, Jatirejo, in Lekok, Pasuruan District and the second village, Paciran, in Lamongan District. In this research sample, there are 89 fisherman households.

Data collection techniques used in the study include (1) extracting initial information from available literature and publications, (2) interviews with respondents to obtain information (in-depth interview), (3) field observation, to get a picture of life day-to-day housekeeping families. In a qualitative approach, the data validity is necessarily tested for the validity, reliability, and the level of trustworthy collected data. Data validity and reliability need testing through testing techniques and verifying findings. [8]. Obtaining the data validity used triangulation technique. Through this testing 


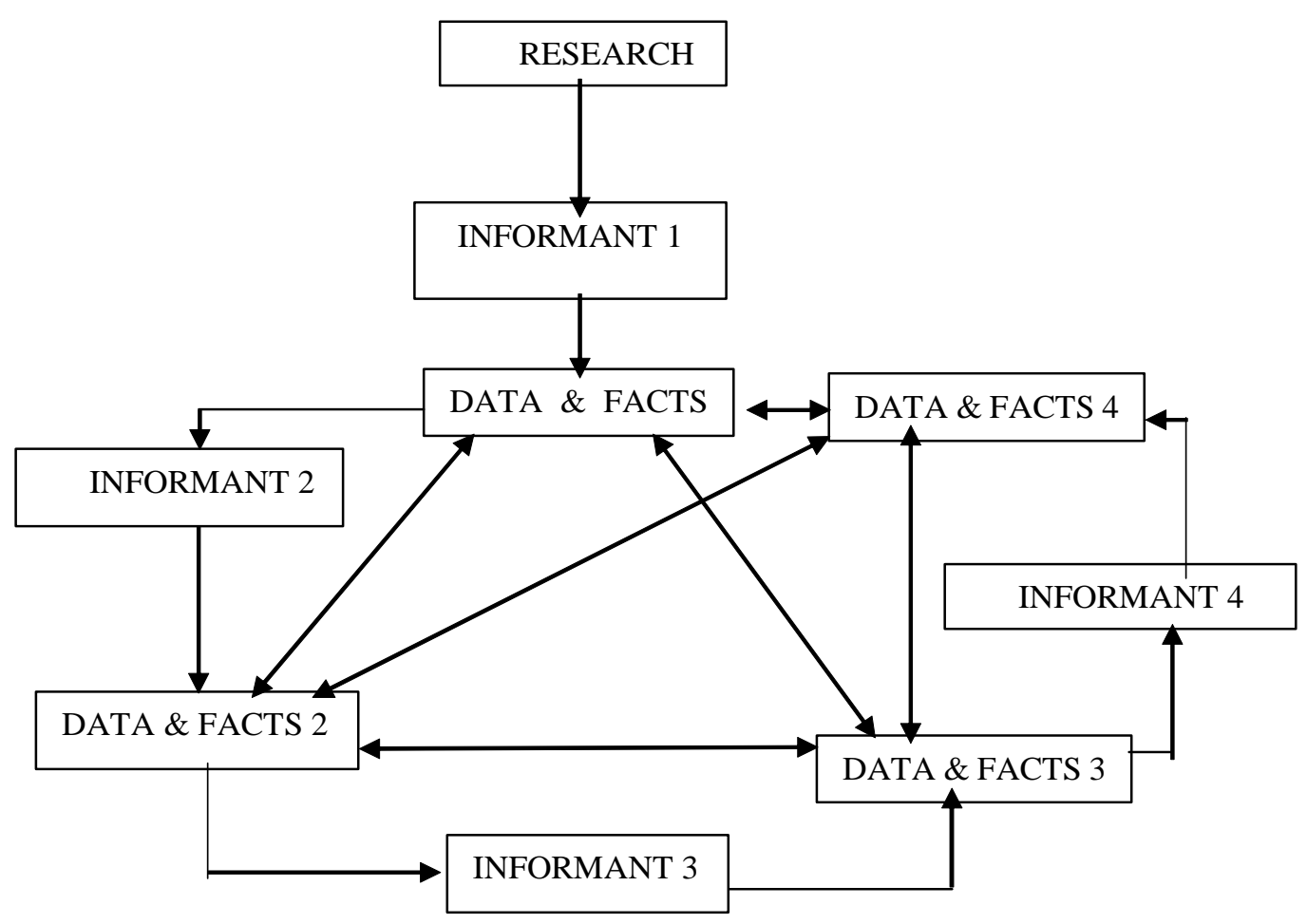

Notes:

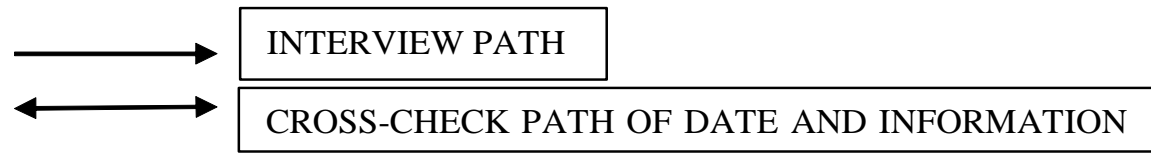

Figure 1 : Triangulation Technique

technique, validity and reliability justify and fulfil the requirements of selected data. Triangulation technique checks the data validity that uses something else outside the data for checking purposes as a comparison of selected data and information.

\section{RESULT}

There are various adaptation strategies that fishermen households have overcome issues on various environmental, social and economic changes. In fishing activities on fishing ground, over fishing has caused fishermen to catch the type of fish in a variety of orientation changes.

Fishermen change the type and amount of fishing gear. In addition to the farther distant catch, the size of the boat is getting bigger. The growing size of this boat cannot be separated from fishermen's necessity to bring more equipment to catch fish. The development of the types of fishing gear used by fishermen prior to 1980 were nets, bringsang net and gondrong net. In the next development between 1980 and 2001, the catch orientation has changed and widely used fishing gear, the blentik net. Furthermore, after the existing fishery resources have been scarce owing to over fishing since 2000, most fishermen, in 2004, switched to catch small crabs using bubu fishing gear. The use of this $b u b u$ was originally adapted by imitating what is done by Rembang fishermen. The size of high bubu is $20-25 \mathrm{~cm}, 50 \mathrm{~cm}$ length and $30 \mathrm{~cm}$ width. Bubu that was thrown into sea filled bait in the form of small fish. Fishers' complaints against the use of this $b u b u$ because the number of traps was disappeared, trawled or stolen by people.

In addition to the changes in the type of fishing gear, the more distant for fishing at sea, fishermen need more size of the boat. In the early use of outboard motors in 1982, the width of the boat was $90 \mathrm{~cm}$, length $7-7.5 \mathrm{~m}$ with machine 5 HP. In 1986, the specification of repaired boats was $100 \mathrm{~cm}$ width, and had $7 \mathrm{HP}$ engine. Furthermore, between 1990 and 2000 the size of the boat became larger in $110 \mathrm{~cm}$ width, 8-9 length and $9 \mathrm{HP}$ engine. Having fished at fishing zones since 2001 until now, over fishing has used the size of the boat. Its size is further enlarged in $120 \mathrm{~cm}$ width, 9 - $10 \mathrm{~m}$ length, and 13 HP engine. By 2018, the width of the boat will have been at $160 \mathrm{~cm}$ and $11 \mathrm{~m}$ length operating 3 pieces of HP machine. The size of the larger boat is not separated from the increasing number of fishing gear brought in the boat, and so is an increasing number of distant catch.

In response to depleted condition of fish stock resources, one form of adaptation strategies by fishermen households is andun or migrating to the South Coast of 
East Java which still has abundant fish resources. The abundant potential of fish resources in the Southern Region of East Java and ZEE is in line with findings [9] that there has been over fishing on the North Coast of East Java, while for southern has been under fishing. Individually, they migrate due to their visionary fishermen looking at their future, whereas the only subsistence-oriented fishermen decide to live and catch fish in their home areas.

Another form of adaptation is to develop other jobs for fishermen and members of their families [10]. There is 61.79 per cent of fishermen households with other sources of income other than fishing by involving children and wives to work in fish processing, fish trade, snack food and work as Indonesian Migrant Workers abroad. However, only 13.48 percent of fishermen becomes the head of the working family, while others are working at sea. For a fisherman, the fish- catching pattern makes it that does not easily do work than go to the sea. Fisherman households diversify their work as one of survival strategies [11].

The industrial developments in coastal areas bring social changes in fishing communities. The more fishermen are reluctant to work as fishermen, the more consuming lifestyle they do. Working in the industrial sectors is more optional. This social change brings the families of fishermen more concerned about their education. The level of education of fishermen's children shows that the children graduated mostly from elementary schools and high schools, and some of them graduated from universities. Consequently, the positive impact on rising awareness about the importance of education causes the declining number of fishermen. The fishermen's children do not work as fishermen as their parents. As a result, data shows the number of fishermen decreases.

Another social change in the fishing community is the emergence of the amount of drug use when fish hunting because the fishermen feel stronger if they drink it. Ship owners must provide drugs for their crew to go to the sea. The drug is a cost component that must be spent in fishing activities at sea.

The emergence of various industries in the coastal areas impacted on the production of water pollution and reduced fish resources. This condition causes a small number of fishermen fish hunting in the outskirts of seashore. They moved the fishing ground further down the sea and increased the size of their boats.

The various adaptation strategies are basically intended to earn household income. Revenues earned are expected to meet the needs of the household properly. Often, the income earned is sufficient to meet subsistence needs, which require the fishermen to reduce their consumption expenditures.

\section{CONCLUSION}

1. The development of industries in coastal areas have a positive and negative impact on the socio economic life of fishermen.
2. The process of adaptation conducted by fishermen households does not only occur in fishing activities, but also in the realm of other types of work on the ground for household members.

3. The fishermen fishing ground has been over fishing. The adaptation strategies are then undertaken by fishermen in: (a) the development of types and quantities of fishing gear when fishing, (b) the diversification of work that can be done by members of household fishermen (c) the migration to new areas due to under fishing reasons.

\section{REFERENCES}

[1] Soemarwoto. Otto, Ekologi, Lingkungan Hidup dan Pembangunan. Jakarta: Djambatan, 1991.

[2] R. George and G. Douglas J., Teori Sosiologi Modern, Edisi ke-6. Terjemahan Alimandan. Jakarta: Kencana Prenada Media Group, 2007.

[3] Singgih and D. Sumbodo, Sistem Sosial. Dalam Sosiologi Teks Pengantar dan Terapan, Ed,: J.Dwi Narwoko-Bagong Suyanto. Jakarta: Kencana Prenada Media Group, 2006.

[4] M. Islam, S. Sallu, K. Hubacek, and J. Paavola, "Limits and barriers to adaptation to climate variability and change in Bangladeshi coastal fi shing communities," Marine Policy, vol. 43, pp. 208-216, 2014.

[5] S. S. Salim and N. Shridhar, "Climate Change Awareness , Preparedness , Adaptation And Mitigation Strategies: Fisherfolks Perception In Coastal Kerala," vol. 2, pp. 670-681, 2014.

[6] M. Makino and Y. Sakurai, "Adaptation to climate-change effects on fisheries in the Shiretoko World Natural Heritage area," Marine Science, vol. 69, no. April, pp. 1134-1140, 2018.

[7] A. Helmi and A. Satria, "Fisher' s Adaptation Strategies to Ecological Changes," Makara, Social Humaniora, vol. 16 No. 1, no. January, pp. 68-78, 2012.

[8] M. Mathew and A. Michael Huberman, Qualitative Data Analysis. Sage Publications Inc., 1992.

[9] T. Anas, "Analisis Perkembangan Produksi Perikanan Tangkap Jawa Timur.” Program PHK A2,Fakultas Pertanian Universitas Muhammadiyah Malang, Malang, 2007.

[10] R. Patriana, "Adaptation Pattern of Fishers in Addressing Climate Change: A Case Study of Fishers in Ciawitali , Pamotan Village, Province Kalipucang Subdistrict, Ciamis Regency of West Java," no. 2, pp. 11-23, 2013.

[11] I. Suardi and A. Cahaya, "Fishermen Poverty and Survival Strategy: Research on Poor Households in Bone Indonesia," Procedia Economics and Finance, vol. 26, no. 15, pp. 7-11, 2015. 